\title{
RECIPROCAL ST SEGMENT CHANGES IN MYOCARDIAL INFARCTION: ISCHEMIA AT DISTANCE VS. MIRROR REFLECTION OF ST- ELEVATION
}

\author{
By \\ Alaa El-Den Mohamed Ali, Ahmed Mohammed Salah El-Din and \\ Mamdouh Helmy El-Tahan \\ Department of Cardiology, Faculty of Medicine, Al-Azhar University \\ Corresponding author: Alaa El-Den Mohamed Ali Gad, \\ Mobile: 01066502085, E-mail: alaaelden2090@ gmail.com
}

\begin{abstract}
Background: ST-elevation myocardial infarction (STEMI) is considered one of the commonest causes of morbidity and mortality all over the world. Nevertheless, survival following acute STEMI showed a considerable improvement as a result of increased symptom recognition, precise diagnosis in addition to effective timely reperfusion.

Objective: To detect the significance of the reciprocal ST segment alterations in the early stage of acute myocardial infarction (AMI) and whether it is truly reciprocal or represents a distant ischemia that might be revealed by coronary angiography.

Patients and methods: This study was conducted on 133 patients admitted to Al-Mokattam Health Insurance Hospital, with the diagnosis of acute STEMI treated with primary percutaneous coronary intervention (PPCI) during the period between November 2018 and December 2019.

Results: Distant ischemia in patients with STEMI undergoing PPCI level was significantly higher in reciprocal ST segment depression (RSTD) group (p-value < 0.001). Besides, multivessel disease (MVD) was more prevalent in RSTD group (36.8\% vs. $17.5 \%)$ in comparison with NRSTD group. The degree of mitral regurge $(\mathrm{MR})$ was more severe among patients with RSTD $(\mathrm{P}$ value $=0.029)$. Mortality rate was more in patients with RSTD, six patients has passed away all of them had RSTD.

Conclusion: The reciprocal changes (RC) caused by interaction of distant ischemia of non-infarcted coronaries and benign mirror electrical alterations, and it has a mortality effect. So, RSTD that was a simple ECG finding used as an indicator of patients at high risk who require a more aggressive approach.
\end{abstract}

Keywords: Reciprocal Changes, Myocardial Infarction, Distant ischemia.

\section{INTRODUCTION}

Myocardial infarction (MI) is considered one of the commonest causes of hospital admission and is widely detected in all people all over the world (Pinaire et al., 2019). In spite of the presence of several examinations that can be carried out in the AMI setting, the electrocardiogram (ECG) is still the widely acknowledged and efficiently performed test for the diagnosis (Fathil et al., 2015).

In the early stages of acute STEMI; there is RSTD that means depression of ST-segment greater than $1 \mathrm{~mm}$ in leads separate \& distinct from leads that reflect 
ST-segment elevation (Thygesen et al., 2018).

The importance of the reciprocal ST segment alterations in the early stage of AMI whether it is pure mirror reflection of ST segment elevation or denotes the presence of ischemia at a distance in noninfarct related arteries that might be revealed by coronary angiography (CA) was an issue that the researchers had thrown a beam of light for years (Quyyimi et al., 2014).

The aim of our study was to determine the significance of the reciprocal ST segment alterations in the early stage of AMI.

\section{PATIENTS AND METHODS}

This study was conducted between November 2018 and December 2019 on 133 patients admitted to Al-Mokattam Health Insurance Hospital, with the diagnosis of acute STEMI treated with PPCI.

\section{Inclusion criteria:}

Continuous chest pain for $\geq 30 \mathrm{~min}$ within the preceding 24 hours; ECG showing ST-segment elevation $2.5 \mathrm{~mm}$ in males of 40 years or less, $2 \mathrm{~mm}$ in males 40 years, or $1.5 \mathrm{~mm}$ in females in leads $\mathrm{V} 2-\mathrm{V} 3$ and/or $1 \mathrm{~mm}$ in the other leads.

\section{Exclusion criteria:}

Left bundle branch block on ECG, paced ECG rhythm, thrombolytic treatment following the diagnosis of STEMI, prinzmetal vasospastic angina and patients refused to be included in the study.

\section{All Patients were subjected to the following:}

\section{Complete clinical work-up including:}

- Demographic data (age and gender)

- Thorough medical history taking for patient's illness and clinical examination.

2. Twelve lead ECG: with special concern to ECG analysis. A STEMI diagnosis was made when ECG changes fit the SD of new ST elevation at the J-point in $\geq 2$ contiguous leads of $\geq 2 \mathrm{~mm}(0.2 \mathrm{mV})$ in males or $\geq 1.5 \mathrm{~mm}$ $(0.15 \mathrm{mV})$ in females in leads V2-V3 and/or of $\geq 1 \mathrm{~mm}(0.1 \mathrm{mV})$ in other contiguous chest leads or the limb leads in addition to one of the following two criteria: duration of chest pain $>30 \mathrm{~min}$ or increased cardiac enzyme markers (Levine et al., 2016). A reciprocal alteration was defined as the existence of a $0.1 \mathrm{mV}$ depression $80 \mathrm{msec}$ after the J-point in $\geq 2$ adjacent leads away from the leads showing ST-segment elevation (Croft et al., 1982).

3. Laboratory investigations: cardiac enzymes, serum creatinin, lipid profile and $\mathrm{CBC}$.

4. Conventional Echocardiography: All patients had subjected to transthoracic echocardiographic study (TTE) using GE Vivid S5, using 3S-RS transducer with frequency bandwidth $1.5-3.6$ MHZ. Examination was carried out while the patient in the left lateral position and simultaneous ECG physio signal was illustrated with all recorded echo images \& loops.

All images and loops of $\geq 3$ conducted cycles were recorded and 
analyzed. TTE M-mode, 2D, Doppler and color flow images.

5. Coronary angiography: In standardized projections CA and PPCI were carried out for each case. Digital

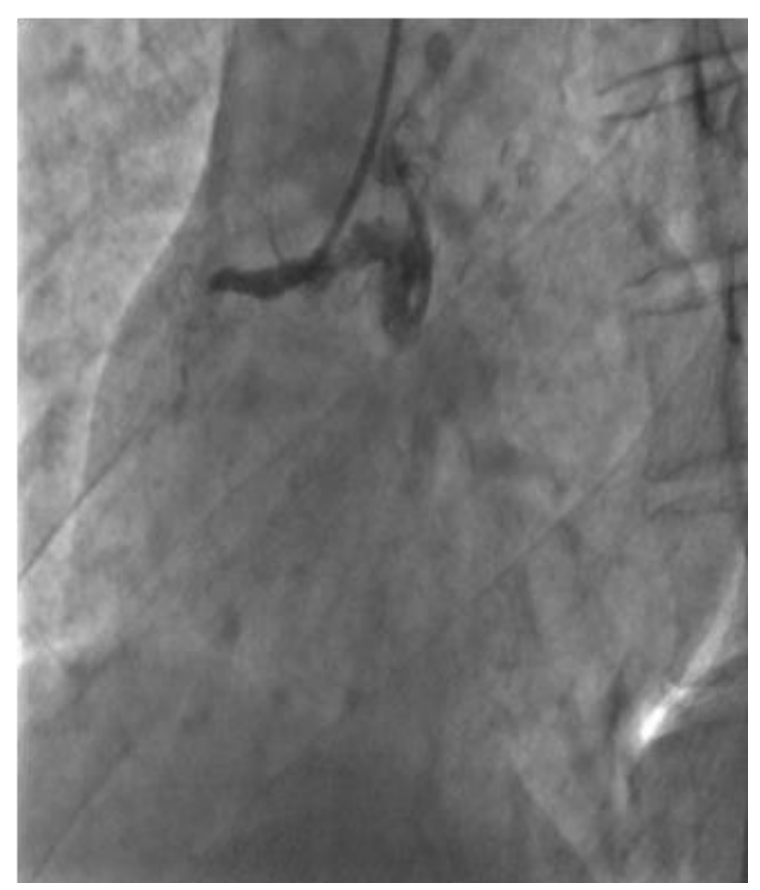

Figure (1): CA of Lt \& Rt coronary arteries revealed total proximal RCA occlusion and significant stenosis in LAD and OM1 (MVD).

\section{Statistical analysis:}

Results were analyzed using the (SPSS) version 23.0 for windows (SPSS Inc., Chicago, IL, USA), NCSS 12 for windows (NCSS LCC., Kaysville, UT, USA).

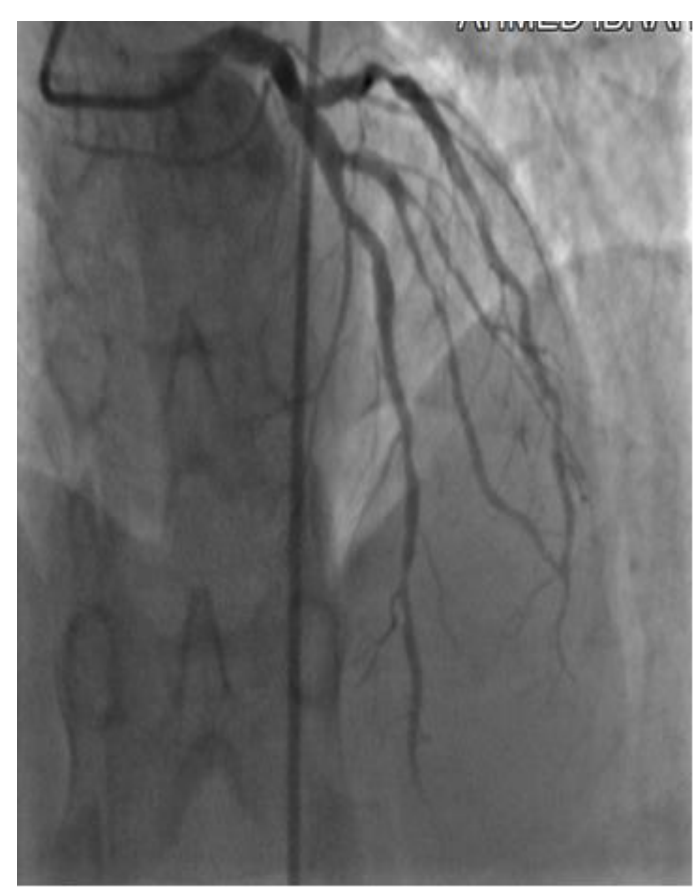

angiograms were then analyzed by an experienced interventional cardiologist who was blind regarding the presence or absence of reciprocal ST segment changes (Figure 1). 


\section{RESULTS}

A total of 133 patients were finally included in the study; 76 has revealed reciprocal alterations (group II) while the other 57 didn't (group I).

The overall mean of age was $59.58 \pm$ $10.68(\mathrm{SD})$ years. On comparing the age distribution among group II (60.39 \pm 9.81$)$ and group I ( $58.97 \pm 11.32)$. There was no statistically significant difference (P-value $=0.453)$ (Table 1).

Table (1): Age distribution of included patients

\begin{tabular}{|c|c|c|c|c|c|c|c|}
\hline \multirow{2}{*}{ Age Groups } & \multicolumn{2}{|c|}{ Group I } & \multicolumn{2}{c|}{ Group II } & \multicolumn{2}{c|}{ Total } & \multirow{2}{*}{$\begin{array}{c}\text { P- } \\
\text { value }\end{array}$} \\
\cline { 2 - 8 } & Mean & SD & Mean & SD & Mean & SD & 0.453 \\
\hline
\end{tabular}

In the study population; there were 120 males and 13 females, in group I (51 males \& 6 females), and in group II (69 males\& 7 females). There was no significant statistical difference between both groups as regard the gender ( $\mathrm{P}$ value $=0.800)$. There were 89 patients $(67 \%)$ smokers in the study population. In group I, 39 patients $(68 \%)$ were smokers while in group II, 50 patients $(66 \%)$ were smokers. There was no significant statistical difference between both groups regarding smoking prevalence $(\mathrm{P}$ value $=$ $0.213)$. In the current study population there were 61 patients (46\%) with diabetes mellitus (DM). In group I, there were 29 patients $(51 \%)$ with DM. In group II, there were 32 patients $(42 \%)$ with DM. There was no significant statistical difference between the 2 groups as regard the prevalence of DM (P value $=0.315)$. Sixty seven patients $(50 \%)$ were hypertensive. In group I, 36 patients (63\%) were hypertensive, whereas in group II, 31 patients $(41 \%)$ were hypertensive. There was significant statistical difference between the 2 groups as regard the prevalence of hypertension $(\mathrm{P}$ value $=0.011)$. Nine patients $(7 \%)$ were chronic kidney disease (CKD) patients. In group I, 4 patients (7\%) were CKD patients while in group II, 5 patients $(7 \%)$ suffered CKD. There was no significant statistical difference between the 2 groups regarding the prevalence of $\mathrm{CKD}$ ( $\mathrm{P}$ value $=0.921)$. Five patients $(4 \%)$ had a positive family history of ischemic heart disease (IHD). In group I, 3 patients (5\%) had a positive family history of IHD while in group II, 2 patients (3\%) had a positive family history of IHD. There was no significant statistical difference between the 2 groups concerning the prevalence of a positive family history of IHD ( $P$ value $=0.430$ ) $($ Table 2). 
Table (2): Baseline demographic data of the whole study population:

\begin{tabular}{|c|c|c|c|c|c|c|c|c|}
\hline \multirow{2}{*}{\multicolumn{2}{|c|}{$\begin{array}{ll}\text { Parameters } & \text { Groups } \\
\end{array}$}} & \multicolumn{2}{|c|}{ Group I } & \multicolumn{2}{|c|}{ Group II } & \multicolumn{2}{|c|}{ Total } & \multirow{2}{*}{$\begin{array}{c}P- \\
\text { value }\end{array}$} \\
\hline & & Count & $\%$ & Count & $\%$ & Count & $\%$ & \\
\hline \multirow{2}{*}{ Gender } & Female & 6 & 10.53 & 7 & 9.21 & 13 & 9.77 & \multirow{2}{*}{0.800} \\
\hline & Male & 51 & 89.47 & 69 & 90.79 & 120 & 90.23 & \\
\hline \multirow{3}{*}{ Smoking } & $\begin{array}{c}\text { Ex- } \\
\text { smoker }\end{array}$ & 2 & 3.51 & 0 & 0.00 & 2 & 1.50 & \multirow{3}{*}{0.213} \\
\hline & No & 16 & 28.07 & 26 & 34.21 & 42 & 31.58 & \\
\hline & Yes & 39 & 68.42 & 50 & 65.79 & 89 & 66.92 & \\
\hline \multirow{2}{*}{$\begin{array}{l}\text { Diabetes } \\
\text { mellitus }\end{array}$} & No & 28 & 49.12 & 44 & 57.89 & 72 & 54.14 & \multirow{2}{*}{0.315} \\
\hline & Yes & 29 & 50.88 & 32 & 42.11 & 61 & 45.86 & \\
\hline \multirow{2}{*}{ Hypertension } & No & 21 & 36.84 & 45 & 59.21 & 66 & 49.62 & \multirow{2}{*}{0.011} \\
\hline & Yes & 36 & 63.16 & 31 & 40.79 & 67 & 50.38 & \\
\hline \multirow{2}{*}{ CKD } & No & 53 & 92.98 & 71 & 93.42 & 124 & 93.23 & \multirow{2}{*}{0.921} \\
\hline & Yes & 4 & 7.02 & 5 & 6.58 & 9 & 6.77 & \\
\hline \multirow{2}{*}{$\begin{array}{l}\text { Family } \\
\text { history } \\
\text { of IHD }\end{array}$} & No & 54 & 94.74 & 74 & 97.37 & 128 & 96.24 & \multirow[b]{2}{*}{0.430} \\
\hline & Yes & 3 & 5.26 & 2 & 2.63 & 5 & 3.76 & \\
\hline
\end{tabular}

CKD: chronic kidney disease, IHD: ischemic heart disease

Killip's Classification at admission between the two groups:

In our study population 106 patients were of Killip's Class I, 19 of Class II, 2 of Class III and 6 of Class 4.

In group I; 52 patients were of Killip's Class I, 4 of Class II, 1 of Class III and 0 of Class 4.
In group II; 54 patients were of Killip's Class I, 15 of Class II, 1 of Class III and 6 of Class 4.

There was statistical significant difference between the 2 groups as regards the difference of Killip's classification at admission, $P$ value $=0.019$ (Table 3) .

Table (3): Comparison of Killip's classification at admission

\begin{tabular}{|c|c|c|c|c|c|}
\hline \multirow{2}{*}{$\begin{array}{c}\text { Killip's class } \\
\text { at admission }\end{array}$} & \multicolumn{2}{|c|}{ Group I } & \multicolumn{2}{c|}{ Group II } & \multirow{2}{*}{ P-value } \\
\cline { 2 - 5 } & Count & $\boldsymbol{\%}$ & Count & $\boldsymbol{\%}$ & \\
\hline I & 52 & 91.23 & 54 & 71.1 & \\
\cline { 1 - 5 } II & 4 & 7.02 & 15 & 19.7 & \multirow{2}{*}{0.019} \\
\cline { 1 - 4 } III & 1 & 1.75 & 1 & 1.32 & \\
\hline IV & 0 & 0 & 6 & 7.89 & \\
\hline
\end{tabular}

The rate of MR by echocardiography between the two groups:

In the current study population; 78 didn't have any MR, 29 patients had mild MR, 16 had moderate MR, 5 had severe MR, 3 had moderate to severe MR and 2 had mild to moderate MR.

In group I; 38 didn't have any MR, 12 patients had mild MR, 4 had moderate MR, and 3 had moderate to severe MR.
In group II; 40 patients did not have any MR, 17 patients had mild MR, 2 had mild to moderate MR, 12 had moderate MR and 5 had severe MR.

There was a significant statistical difference between the 2 groups as regard the prevalence of MR, $\mathrm{P}$ value $=0.029$ (Table 
Table (4): Comparison of the MR rates in the two groups

\begin{tabular}{|c|c|c|c|c|c|c|c|}
\hline \multirow{2}{*}{$\begin{array}{l}\text { Mitral Groups } \\
\text { regurgitation }\end{array}$} & \multicolumn{2}{|c|}{ Group I } & \multicolumn{2}{c|}{ Group II } & \multicolumn{2}{c|}{ Total } & \multirow{2}{*}{ P-value } \\
\cline { 2 - 8 } & Count & $\boldsymbol{\%}$ & Count & $\%$ & Count & \% & \\
\hline None & 38 & 66.67 & 40 & 52.63 & 78 & 58.65 & \\
\hline Mild & 12 & 21.05 & 17 & 22.37 & 29 & 21.80 & \\
\hline Mild to moderate & 0 & 0.00 & 2 & 2.63 & 2 & 1.50 & \multirow{2}{*}{0.029} \\
\hline Moderate & 4 & 7.02 & 12 & 15.79 & 16 & 12.03 & \\
\hline Moderate to severe & 3 & 5.26 & 0 & 0.00 & 3 & 2.26 & \\
\hline Severe & 0 & 0.00 & 5 & 6.58 & 5 & 3.76 & \\
\hline
\end{tabular}

Distant Ischemia by invasive coronary angiography between the two groups:

In our study population 87 patients had distant ischemia and 46 did not have distant ischemia.

In group I; 29 patients had distant ischemia, 10 of them were MVD and 28 patients didn't have distant ischemia.
In group II; 58 patients had distant ischemia, 28 of them were MVD and 18 patients didn't have distant ischemia.

There was a significant statistical difference between the 2 groups regarding the prevalence of distant ischemia, $\mathrm{P}$ value $<0.001$ (Table 5).

Table (5): Comparison of Distant ischemia (stratified by Infarct Location)

\begin{tabular}{|c|c|c|c|c|c|c|c|c|c|}
\hline \multirow{4}{*}{$\begin{array}{l}\text { Groups } \\
\text { Distant } \\
\text { ischemia }\end{array}$} & \multicolumn{4}{|c|}{ Group I } & \multicolumn{4}{|c|}{ Group II } & \multirow{4}{*}{$\begin{array}{c}P \text { - } \\
\text { value }\end{array}$} \\
\hline & \multicolumn{8}{|c|}{ Infarct Location } & \\
\hline & \multicolumn{2}{|c|}{ Anterior } & \multicolumn{2}{|c|}{ Inferior } & \multicolumn{2}{|c|}{ Anterior } & \multicolumn{2}{|c|}{ Inferior } & \\
\hline & Count & $\%$ & Count & $\%$ & Count & $\%$ & Count & $\%$ & \\
\hline No & 23 & 48.9 & 5 & 50 & 13 & 39.4 & 5 & 11.6 & \\
\hline MVD & 7 & 14.9 & 3 & 30 & 7 & 21.2 & 21 & 48.8 & \\
\hline LAD & 0 & 0 & 2 & 20 & 0 & 0 & 10 & 23.3 & \\
\hline LCX & 6 & 12.8 & 0 & 0 & 6 & 18.2 & 3 & 6.98 & \\
\hline RCA & 9 & 19.2 & 0 & 0 & 4 & 12.1 & 2 & 4.65 & $<0.001$ \\
\hline OM & 0 & 0 & 0 & 0 & 0 & 0 & 2 & 4.65 & \\
\hline Diagonal & 0 & 0 & 0 & 0 & 3 & 9.09 & 0 & 0 & \\
\hline PDA & 1 & 2.13 & 0 & 0 & 0 & 0 & 0 & 0 & \\
\hline Ramus & 1 & 2.13 & 0 & 0 & 0 & 0 & 0 & 0 & \\
\hline
\end{tabular}

MVD: multi vessel disease, LAD: left anterior descending artery, LCX: left circumflex artery, RCA: right coronary artery, OM: obtuse marginal, PDA: posterior descending artery.

\section{Complications that appeared in the two groups:}

In the present study population; 6 patients have passed away, 6 patients suffered acute pulmonary edema and 5 had cardiogenic shock.

In group I; no patients have passed away, 2 patients suffered acute pulmonary edema, 2 patients had atrial fibrillation, 2 patients had ventricular tachycardia and 2 patients had Contrast-induced nephropathy.
In group II; 6 patients have passed away, 4 patients suffered acute pulmonary edema, 5 had cardiogenic shock and 3 had no reflow/Congested.

The vast majority of the studied participants had no follow up complication (74.44\%); $(82.46 \%$ vs. $68.42 \%$ ) in group (I) and group (II) respectively with no statistically significant difference between both studied groups regarding the prevalence of complications, $\mathrm{P}$ value $=0.172($ Table 6) . 
Table (6): Comparison of the follow up complications

\begin{tabular}{|c|c|c|c|c|c|c|c|}
\hline \multirow{2}{*}{$\begin{array}{l}\text { Follow up Groups } \\
\text { complications }\end{array}$} & \multicolumn{2}{|c|}{ Group I } & \multicolumn{2}{|c|}{ Group II } & \multicolumn{2}{|c|}{ Total } & \multirow{2}{*}{$\begin{array}{c}P \text { - } \\
\text { value }\end{array}$} \\
\hline & Count & $\%$ & Count & $\%$ & Count & $\%$ & \\
\hline Cardiogenic shock & 0 & 0.00 & 5 & 6.58 & 5 & 3.76 & \multirow{9}{*}{0.172} \\
\hline $\begin{array}{l}\text { Acute pulmonary } \\
\text { edema }\end{array}$ & 2 & 3.51 & 4 & 5.26 & 6 & 4.51 & \\
\hline $\begin{array}{l}\text { Ventricular } \\
\text { tachycardia }\end{array}$ & 2 & 3.51 & 2 & 2.63 & 4 & 3.01 & \\
\hline $\begin{array}{l}\text { Contrast-induced } \\
\text { nephropathy }\end{array}$ & 2 & 3.51 & 2 & 2.63 & 4 & 3.01 & \\
\hline Atrial Fibrillation & 2 & 3.51 & 1 & 1.32 & 3 & 2.26 & \\
\hline No reflow/Congested & 1 & 1.75 & 3 & 3.95 & 4 & 3.01 & \\
\hline $\begin{array}{c}\text { Mobitz II and } \\
\text { temporary pacemaker } \\
\text { plus DKA }\end{array}$ & 1 & 1.75 & 0 & 0.00 & 1 & 0.75 & \\
\hline $\begin{array}{l}\text { MVD for urgent } \\
\text { CABG }\end{array}$ & 0 & 0.00 & 1 & 1.32 & 1 & 0.75 & \\
\hline Death & 0 & 0.00 & 6 & 7.89 & 6 & 4.51 & \\
\hline
\end{tabular}

DKA: diabetic ketoacidosis, MVD: multi vessel disease, CABG: coronary artery by-pass grafting

\section{DISCUSSION}

The significance of reciprocal ST segment changes in STEMI patients has been an area of debate over years, whether it is a sign of MVD, ischemia at a distance, poor prognosis and early mortality or only a benign electrical phenomenon.

Non-significant difference was observed between the two groups regarding age and genders as the vast majority of patients were males. The mean age was $59.58 \pm 10.68$. These findings were in accordance with the study carried out by Nour (2017) that there was no significant difference between age and gender in relation to reciprocal ST changes. This study revealed no significant difference as regard DM with existence or absence of reciprocal ST changes in STEMI patients. In contrast they concluded more prevalence of DM with presence of reciprocal ST changes. In addition, there was a significant difference between the studied groups as regard the difference of Killip's classification at admission, in contrast to the study conducted by Chen et al. (2012) on 165 patients with STEMI receiving immediate invasive intervention who revealed no significant difference between both groups regarding Killip's class. In contrast to Nour (2017) concluded no significant relationship between the prevalence of systemic hypertension and the existence or absence of reciprocal ST changes in STEMI patients, in the current study systemic hypertension was more prevalent in patients without reciprocal ST changes.

As regard to $\mathrm{CKD}, \mathrm{CKD}$ as a risk factor in correlation with reciprocal ST changes was documented for the 1st time in the current evidence. However, there was no significant statistical difference between the 2 groups.

As regard distant ischemia: we observed that distant ischemia and MVD were more prevalent in patients with 
ALAA EL-DEN MOHAMED ALI et al.,

reciprocal changes. A statistically significant difference was detected between both groups regarding distant ischemia, this finding was in harmony with that stated by Nour (2017) who studied the correlation between ST segment depression and the extent of coronary artery disease (CAD) and found patients with acute MI who presented with RSTD have higher incidence of multivessel coronary artery disease on their coronary angiograms. Similarly in the study conducted by Hekim et al. (2010) concluded that the presence of RSTD in precordial leads was accompanied by more frequent LAD disease, and Noriega et al. (2014) found that significant stenosis in arteries opposite to the culprit vessel resulted in reciprocal ST-depression. On the Contrary, Quyyimi et al. (2014) in a study of controlled coronary occlusion during angioplasty postulated that reciprocal changes isn't common in MVD patients when in comparison with those with single vessel disease; nevertheless, this study enrolled small sample size (21 patients only) and included patients suffered anterior MI and LAD lesions. In addition, they reported ST changes occurred at time of balloon inflation of the LAD artery.

As regards maximum ST segment elevation: patients with reciprocal ST changes had higher ST elevation in comparison with patients without. However, no significant statistical difference was determined between both groups. This was in coherence with a study conducted by Vaidya et al. (2018) who showed no significant statistical difference in the maximum height of ST elevation in relation to existence of reciprocal ST depression in STEMI patients. Discordant to our results $E l$ Atroush et al. (2012) who reported that extent of ST segment elevation in inferior leads was significantly increased in the group with RSTD in comparison with the group without. The discrepancy between their results \& ours might be explained by the difference in the clinical settings (inferior MI in their study in comparison to anterior and inferior MI in our study).

Regarding maximum ST depression in $\mathrm{mm}$ in relation to distant ischemia, maximum ST-Segment depression in (mm) was slightly increased among studied cases with distant ischemia, however; the maximum ST segment depression in (mm) showed nonstatistically significant difference in relation to distant ischemia. Similarly $E l$ Atroush et al. (2012) concluded no correlation between degree of depression of ST segment on admission and degree of LAD lesion.

As regard degree of MR: patients with RSTD have greater degree of MR in comparison with patients without RSTD. This was in accordance with findings of El Atroush et al. (2012) who revealed a higher incidence of MR in patients with RSTD.

In the current study, the vast majority of the studied participants had no follow up complication (Arrhythmia, pulmonary edema, CIN, cardiogenic shock and death) (74.44\%) with no statistically significant difference between both studied groups as regard the prevalence of complications. In contrast to our results, El Atroush et al. (2012) reported the presence of significant statistical difference of complications between group 1 with 
RSTD and group 2 without RSTD (the statistical significance might be explained by the fact that they have included MR in the complications in their study).

\section{CONCLUSION}

The reciprocal ST segment changes caused by the interaction of distant ischemia of non-infarcted coronaries arteries and benign mirror electrical changes, and it had a mortality impact. So, RSTD that was a simple ECG finding can be used as an indicator of high risk patients who will require a more aggressive approach.

Conflict of interest: No conflicts of interest were encountered.

\section{REFERENCES}

1. Chen, T. E., Lo, P. H., Li, T. C., Lin, K. H., Lin, J. J., Hsieh, L. C., Chang, C. P., Chen, Y. P., Chang, K. C. and Wang, H. J. (2012): Prognostic Significance of Reciprocal STSegment Depression in Patients with Acute STEMI Undergoing Immediate Invasive Intervention. American Journal of Emergency Medicine, 30(9):1865-71.

2. Croft, C. H., Woodward, W., Nicod, P., Corbett, J. R., Lewis, S. E., Willerson, J. T. and Rude, R. E. (1982): Clinical implications of anterior s-t segment depression in patients with acute inferior myocardial infarction. Am $\mathbf{J}$ Cardiol, 50: 428-436.

3. El Atroush, H., Effat, H., Shehata, M. and Emara, H. (2012): Reciprocal ST Segment Changes in Acute Inferior Myocardial Infarction: Clinical, Hemodynamic and Angiographic Implications. Egyptian Heart Journal, 64(3):97-103.

4. Fathil MF, Arshad MM, Gopinath SC, Hashim U, Adzhri R, Ayub RM, Ruslinda AR, Nuzaihan M, Azman AH, Zaki M and Tang TH. (2015): Diagnostics on acute myocardial infarction: Cardiac troponin biomarkers. Biosensors and Bioelectronics, 15:70:209-220.
5. Hekim K, Mehmed Y, Yusuf K, Zekeriya K, Hasan K, Selcuk P, Mehmet $Y$ and Ahmet Y. (2010): Importance of Reciprocal STSegment Depression in the extensive coronary artery disease. Eur J Gen Med., 7(1):88-91.

6. Levine GN, Bates ER, Bittl JA, Brindis RG, Fihn SD, Fleisher LA, Granger CB, Lange RA, Mack MJ, Mauri L and Mehran R. (2016): ACC/AHA guideline focused update on duration of dual antiplatelet therapy in patients with coronary artery disease: A report of the american college of cardiology/american heart association task force on clinical practice guidelines. Circulation, 134, e123-e155.

7. Noriega, F. J., Vives-Borras, M. and SoleGonzalez, E. (2014): Influence of the Extent of Coronary Atherosclerotic Disease on STSegment Changes Induced by ST Elevation Myocardial Infarction. Am J Cardiol., 113:757-764.

8. Nour, M. K. (2017): Significance of reciprocal ST segment depression in ST elevation myocardial infarction. The Egyptian Journal of Critical Care Medicine, 5(1): 23-27.

9. Pinaire, J., Azé, J., Bringay, S., Cayla, G. and Landais, P. (2019): Hospital burden of coronary artery disease: Trends of myocardial infarction and/or percutaneous coronary intervention in France. PLOS ONE; 14: e0215649.

10. Quyyumi, A. A., T. Crake, M. B. Rubens, R. D. Levy, A. F. Rickards, and K. M. Fox. (2014): Importance of 'Reciprocal' Electrocardiographic Changes during Occlusion of Left Anterior Descending Coronary Artery. Studies during Percutaneous Transluminal Coronary Angioplasty. Lancet (London, England), 1(8477):347-50.

11. Thygesen, K., Alpert, J. S., Jaffe, A. S. and Chaitman, B. R. (2018): Fourth universal definition of myocardial infarction. Eur Heart J, 40, 237-269.

12. Vaidya, G. N., Antoine, S., Imam, S. H., Kozman, H., Smulyan, H., \& Villarreal, D. (2018): Reciprocal ST-Segment Changes in Myocardial Infarction: Ischemia at Distance versus Mirror Reflection of ST-Elevation. American Journal of the Medical Sciences, 355(2):162-67. 
التفيرات المتقابلة لقطمة ال اس تي في حالات إحثشاء القلب: ثقص

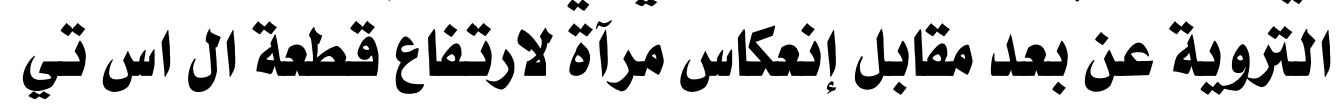
علاء الدين محمد علي، أحمد محمد صلاح الدين أحمد، ممدوح حلمي الطحان قسم القلب والاوعية الاموية، كلية طب الأزهر، القاهرة

E-mail: alaaelden2090@gmail.com

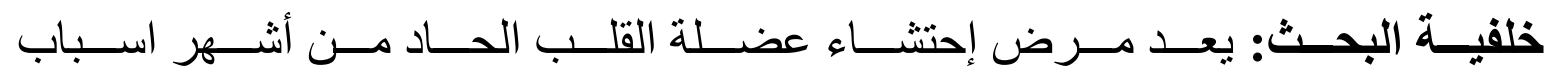
الوفاة في العالم، ومن المهم سر عة تثخيصه و التعامل الجيد معله.

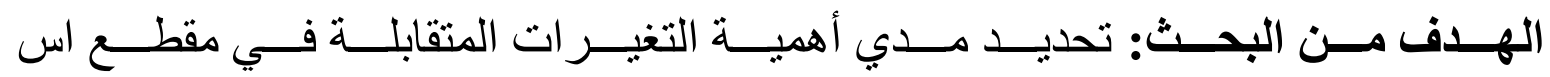

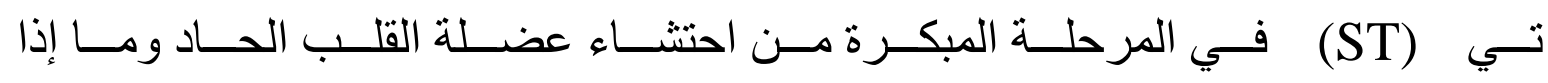

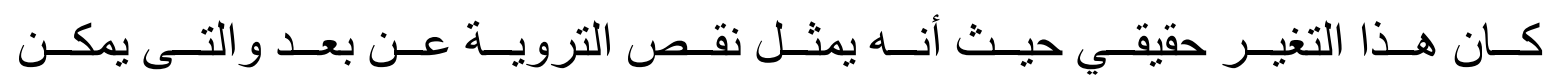

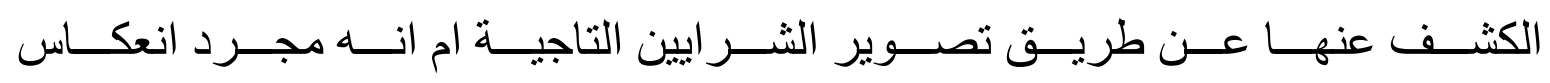
لارتفاع مقطع ال اس تي في هذه الحالات.

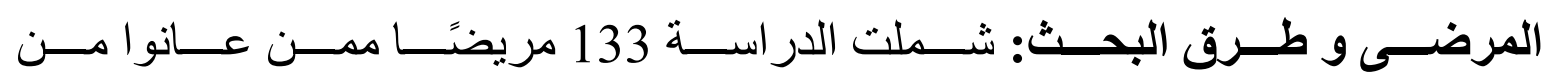

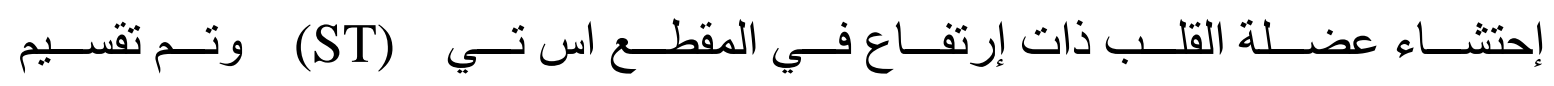

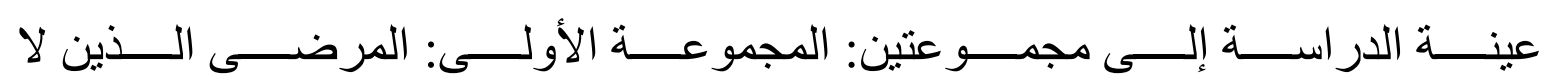

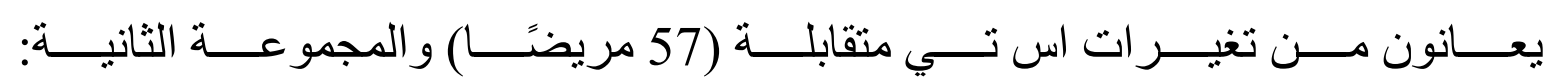

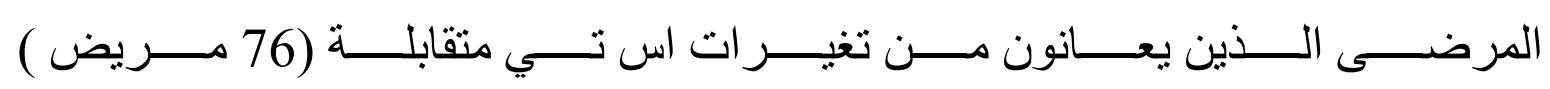

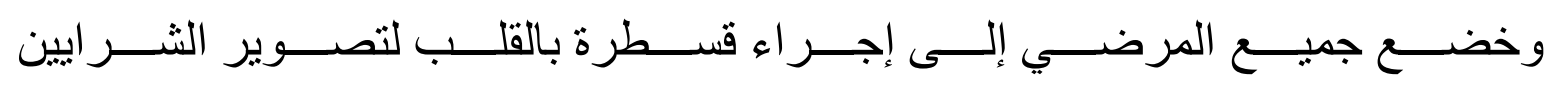

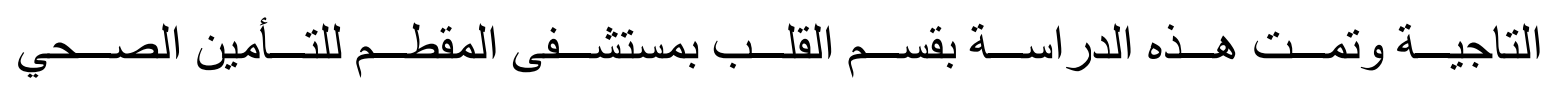
في الفترة من نوفمبر 2018 الى ديسمبر 2019.

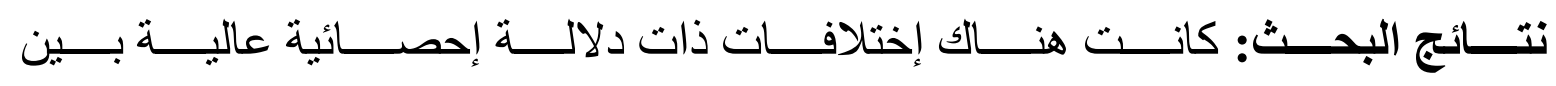

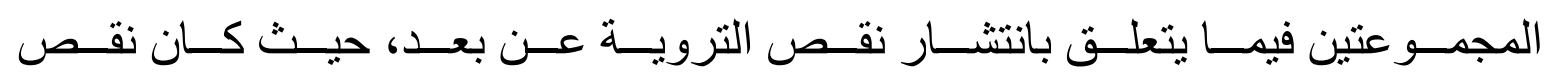

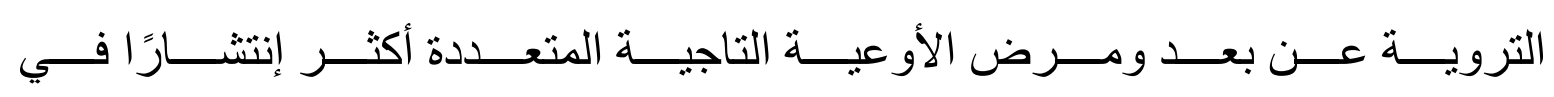




\section{RECIPROCAL ST SEGMENT CHANGES IN MYOCARDIAL...}

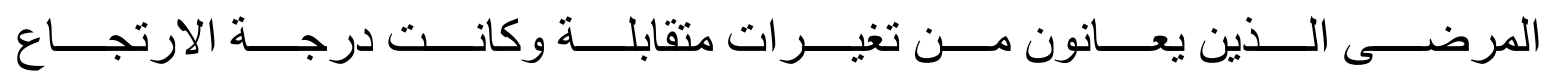
بالصـــمام المتر الــي اكثتـر فــي المرضـــي الـذذين بعــانون مــن تغيــر ات اس تــي منقابلة.

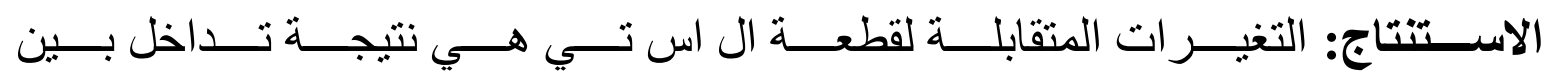

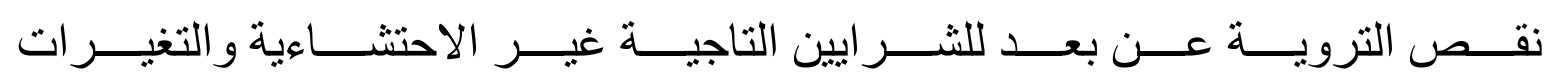

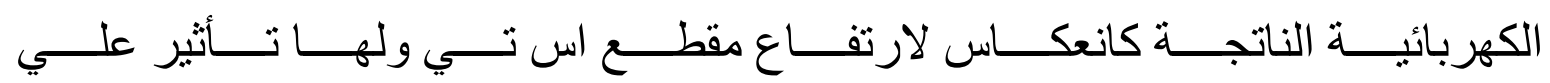

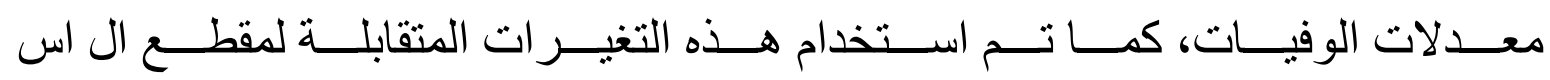

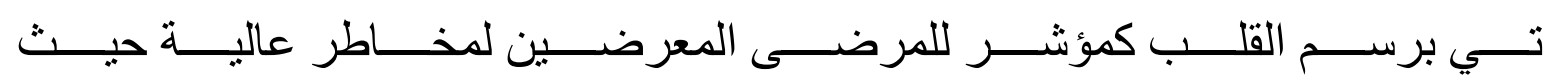
يحتاجون إلى رعاية فائقة.

الكلمات الدالة: التغير ات المتقابلة، إحتثاء القلب، نقص التروية. 